\title{
Head of an old goitrous woman
}

\author{
Enio Martino ${ }^{1}$
}

Received: 24 February 2017 / Accepted: 24 February 2017 / Published online: 25 April 2017

(C) Italian Society of Endocrinology (SIE) 2017

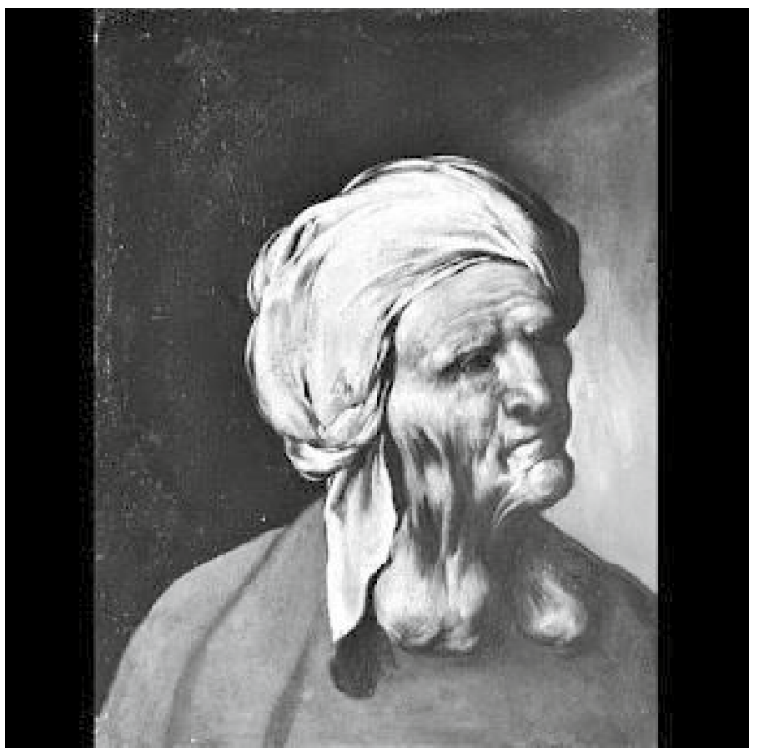

Francesco Fracanzano (Monopoli 1612- Napoli 1656) Testa di vecchia gozzuta

Archivio di Federico Zeri - Collezione Privata- Italia

Francesco Fracanzano was born in Monopoli, near Barisouthern Italy in 1612 and died in Naples in 1656. Father, brother, and son were also painters. He was somewhat violent and he was condemn for many criminal offense. In Naples, he was a pupil of Joseph De Ribera called "Lo Spagnoletto" and he grew in the Caravaggesca School of Art, whose painters describe frequently subjects with goiter such as Artemisia Gentileschi [1] and Caravaggio himself [2]. The major part of his works are located in churches and museums of Naples (i.e., San Gregorio Armeno), although some are exposed in Vienna, Paris, and New York's museums. This picture (private collection of Archives Federico Zeri-IT), which is evident Lo Spagnoletto influence [3], is depicted the head of an old woman with an evident and large multinodular goiter and venous dilatation.

\section{Compliance with ethical standards}

Conflict of interest The authors have no conflict of interest.

Ethical approval No ethical approval was required for this article.

Informed consent Informed consent was not applicable to this article.

\section{References}

1. Trimarchi F (2016) Judith and her Maidservant: a goitrous heroin in two masterpieces. J Endocrinol Invest 39:1357-1358

2. Traversari M et al. (2016) The "Lost Caravaggio": a probable case of goiter in seventeenth-century Italy. J Endocrinol Invest 39:1203-1204

3. Nicoli F et al. (2016) "The Penitent Magdalene": Jusepe de Ribera (1591-1652). J Endocrinol Invest (Epub ahead of print)

Enio Martino

enio.martino@gmail.com

1 University of Pisa, Pisa, Italy 